\title{
ANALISIS PROGRAM ENTREPRENEUR ENABLER DENGAN METODE PARTICIPATORY ACTION LEARNING SYSTEM
}

\author{
Srinathasya Br Sitepu ${ }^{1}$ \\ ${ }^{1}$ Jurusan Manajemen, Universitas Ciputra Surabaya \\ Email: nathasya.sitepu@ciputra.uc.ac.id
}

\begin{abstract}
ABSTRAK
Program entrepreneur enabler diberikan kepada karyawan KPSP Setia Kawan Nongkojajar di Kabupaten Pasuruan memakai metode participatory action learning system (PALS). Jumlah karyawan yang mengikuti pelatihan sebanyak 300 orang. Tujuan kegiatan ini meningkatkan kompetensi karyawan dan menciptakan pendapatan tambahan melalui bisnis yang diciptakan oleh karyawan. Program ini menerapkan metode PALS melalui empat tahapan yang yaitu: capaciting, komunikasi, soft skill dan entrepreneur enabler. Program ini berhasil meningkatkan kompetensi karyawan ditandai dengan: upgrade kapasitas dari masing-masing karyawan, peningkatan kemampuan komunikasi dan lahirnya 30 karyawan sekaligus berperan sebagai entrepreneur enabler yang berhasil menciptakan bisnis diluar jam kerja. Bisnis yang dijalankan entrepreneur enabler mampu menghasilkan pendapatan tambahan diluar gaji.
\end{abstract}

Kata kunci: entrepreneur enabler, PALS

\section{PENDAHULUAN}

Kabupaten Pasuruan berada di provinsi Jawa Timur. Koperasi KPSP Setia Kawan yang berada di Desa Nongko Jajar. Koperasi KPSP Setia Kawan memiliki 8000 anggota yang berada disekitar lereng barat pegunungan tengger.400-2000 mdpl. Koperasi ini berdiri sejak tahun 1911 pada masa penjajahan Belanda. Koperasi KPSP Setia Kawan Nongkojajar merupakan salah satu penggerak ekonomi di Kabupaten Pasuruan. Hal ini dapat dilihat dari kapasitas produksi susu sebesar 8.900 liter/hari dan ditambah dengan penghasilan dari divisi minimarket serta divisi simpan pinjam. Unit bisnis utama koperasi KPSP Setia Kawan bergerak dibidang susu sapi perah dan didukung oleh unit minimarket, cafe, penjualan pakan ternak dan unit simpan pinjam. Pengoprasian kegiatan koperasi didukung oleh 300 karyawan. Setiap karyawan disebar pada beberapa divisi diantaranya: a). divisi perdagangan dan jasa, b). Simpan Pinjam, c). Ternak, d). Divisi susu segar, e). Divisi perkantoran dan administrasi. Karyawan koperasi KPSP Setia Kawan Nongkojajar memiliki latar belakang pendidikan Sekolah Dasar (SD) hingga Master dibidang manajemen. Mayoritas pendidikan karyawan KPSP Setia Kawan Nongkojajar Sekolah Dasar (SD) hingga Sekolah Menegah Atas (SMA). Tingkat pendidikan ini merupakan alasan kurang maksimalnya output yang dihasilkan karyawan serta besaran pendapatan yang belum maksimal untuk memebuhi kebutuhan hidup. Tingkat pendidikan karyawan menjadi kendala bagi manajemen untuk memaksimalkan daya saing koperasi dalam dunia bisnis.

Karyawan mengalami kesulitan dari aspek internal karyawan, dan eksternal karyawan. Internal karyawan berhubungan dengan karakter dan kapasitas setiap karyawan. Aspek eksternal terdiri dari: budaya organisasi, penggunaan tools/teknologi (system 
komputerisasi), soft skill (komunikasi dan penguasaan bahasa Inggris). Keterbatasan aspek internal dan eksternal karyawan menimbulkan masalah dilapangan antara lain: a). data laporan dari kesehatan hewan dan up-date jumlah susu segar masih membutuhkan waktu (offline) hal ini yang mempersulit manager untuk mengambil keputusan. b). Data inventori dari divisi perdagangan kurang akurat karena masih menggunakan kartu stok sehingga setiap bulan terjadi selisih barang. c). Jalur koordinasi antar divisi menggunakan berita acara atau surat manual sehingga membutuhkan waktu dan biaya yang relative lebih besar. d). Keterbatasan kemampuan komunikasi menggunakan bahasa asing (Inggris) sehingga harus menggunakan jasa penerjemah. e). Time management dari setiap karyawan belum dialokasikan dengan baik sehingga pekerjaan tidak ontime. f). Kebutuhan untuk menemukan peluang bisnis tambahan untuk meningkatkan pendapatan koperasi. g). Karyawan KPSP Setia Kawan sebagian besar memiliki masa kerja yang cukup panjang sekitar 3 tahun - 35 tahun. Hal ini menjadikan karyawan bekerja dengan monoton sehingga tidak jarang karyawan merasa jenuh. Masa kerja karyawan yang relative lama membuat karyawan loyal namun sulit untuk melakukan inovasi karena sudah merasa nyaman. h). Karyawan membutuhkan tambahan pendapatan karena peningkatan kebutuhan tidak sebanding dengna peningkatan pendapatan sebagai karyawan. Masalah-masalah yang berhasil diidentifikasi selanjutnya ditindak lanjuti oleh Universitas Ciputra dalam bentuk Program Pengabdian Masyarakat (PKM) yang bertujuan untuk membantu koperasi KPSP Setia Kawan menyelesaikan masalah yang ada pada koperasi.

\section{METODE PELAKSANAAN PROGRAM PKM}

Universitas Ciputra mengadakan program entrepreneur enabler yang merupakan bentuk dari Pengabdian Kepada Masyarakat (PKM). Entrepreneur enabler merupakan seseorang pengusaha yang membuat sesuatu menjadi mungkin (kemampuan berinovasi). Beberapa karakter yang harus dimiliki entrepreneur enabler diantara lain: a). Mengetahui kekuatan dan kelemahan dari sendiri, b). Mengetahui potensi diri dan target yang ingin dicapai, c). Membangun jaringan bisnis, mempelajari dan bertidak seperti pebisnis yang sukses, d). melakukan identifikasi komponen biaya mendirikan bisnis, list alamat dari supplier, e). Pemilihan teknik dan konsep bisnis yang sesuai dengan kebutuhan entrepreneur enabler kelompok (Thompson, J., \& Downing, R., 2007). Selain karakter entrepreneur enabler juga harus mengikuti proses pembelajaran entreprneurship dimana keberhasilan dari proses pembelajaran dapat diukur melalui tujuh indicator diantaranya: kepemimpinan, pengasaaan informasi dan analisis, perencanaan dan strategi operasional, manajemen sumber daya manusia, hasil kinerja dari pembelajaran, dan fokus dari entrepreneur (Vesper, K. H., \& Gartner, W. B. 1997). Proses pendidikan akan meningkatkan pengetahuan dari entrepreneur. Keseimbangan antara aspek pengetahuan, bakat, potensi setiap individu mampu meningkatkan value dan inovasi dalam menjalankan bisnis (Rae, D. 2017).

Penerapan program entrepreneur enabler dilaksanakan dengan metode PALS (Participatory Action Learning System) pada karyawan KPSP Setia Kawan bertujuan agar karyawan aktif dalam proses pembelajaran baik secara individu maupun kelompok. Metode PALS melatih kemandirian karyawan untuk mengingkatkan kompetensi di dunia kerja serta membuka sebuah bisnis sesuai dengan penelitian Kassean, et al, (2015) mengatakan kemandirian kewirausahaan dari peserta (ESE) merupakan kekuatan untuk pendorong aktivitas proses pembelajaran sehingga meningkatkan minat peserta pelatihan. Pentingnya pembelajaran yang berbasis participatory action ditemukan Brink, T., \& Madsen, S. O. (2015) dimana, manajer UKM memakai metode treatment lintas disiplin yang berbentuk praktek, holistik untuk belajar. Pendekatan pembelajaran mengkolaborasi teori dan praktek bisnis (masalah) yang muncul pada saat eksekusi. Keterbukaan manajer terhadap ilmu baru oleh serta kolaborasi lintas ilmu/kapasitas antara manajer UKM dengan fasilitator / peneliti universitas menjadi kunci utama yang sangat diperlukan. Hietanen, L., 
\& Järvi, T. (2015) mengemukakan kompetensi entrepreneurship bukanlah satu-satunya aspek terpenting melainkan dibutuhkan tambahan pengetahuan lainnya seperti: komunikasi, bahasa asing dan teknologi. Melalui metode PALS, karyawan KPSP Setia Kawan diharapkan mampu menunjukkan perubahan kearah yang lebih baik terhadap peningkatan potensi diri dari setiap karyawan melalui beberapa tahapan yaitu:

\section{Tahap pengkapasitasan (capaciting)}

Tahapan meningkatkan kapasitas dari karyawan koperasi melalui rangkaian pelatihan (tahap 1-4). Karyawan diberikan pelatihan setiap satu tahun sekali untuk meningkatkan kompetensi dan kemampuan karyawan dalam menyelesaikan permasalahan yang terjadi pada kegiatan operasional koperasi. Adapun detail tahapan pelatihan sebagai berikut:

Tahapan pertama Pelatihan aspek internal penggalian potensi diri(Karakter, Potensi, Motivasi dan time management). Pelatihan tahap kedua dilakukan pada tahun 2015 dengan focus pelatihan untuk membangkitkan motivasi/semangat karyawan untuk bekerja dan time management dari setiap karyawan. Pelatihan memberikan konten konsep dan juga praktek dari menyusun time management. Setiap dibekali kesempatan coaching, diberikan kisah inspirative dan melakukan napak tilas perjalanan koperasi KPSP Setia Kawan Nongkojajar dari awal berdiri hingga tahun 2015.

Pelatihan dilakukan selama empat minggu (karyawan berada dalam camp) dan selanjutnya karyawan koperasi KPSP Setia Kawan selama 6 bulan akan melakukan praktek di korperasi. Pada saat praktek karyawan dibekali dengan list kegiatan yang berhubungan dengan motivasi dan time managmenet yang harus dipraktekkan. Tim PKM akan melakukan evaluasi dari praktek karyawan terkait aspek individu (fokus pada motivasi dan time managmenet). Pasca kegiatan evaluasi maka Tim PKM melakukan FGD dengan karyawan terkait progress/pencapaian karyawan pada aspek individu (motivasi dan time management).

\section{Tahap Pelatihan aspek internal (Komunikasi)}

Pelatihan tahap 2 dilakukan pada tahun 2016 dengan focus pelatihan pada aspek individu (komunikasi). Karyawan KPSP Setia Kawan dibekali dengan teori komunikasi verbal maupun komunikasi non-verbal. Tujuan pemberian teori komunikasi agar menambah pengetahuan karyawan akan konsep komunikasi yang benar. Setelah mendapatkan konsep teori komunikasi karyawan juga mendapatkan kesempatan praktek komunikasi dengan pakar komunikasi.

Teori komunikasi yang didapatkan karyawan dari camp selama dua minggu selanjutnya mulai diterapkan saat bekerja di koperasi. Karyawan diberikan worksheet yang harus setiap hari diisi untuk melihat progress kemampuan karyawan dalam berkomunikasi. Tim PKM Universitas Ciputra melakukan monitoring untuk melihat sejauh mana progress masing-masing karyawan dalam berkomunikasi. Tim PKM yang melakukan mentoring dengan waktu yang random serta mengevaluasi kemampuan komunikasi dari setiap divisi. Khususnya divisi susu segar dan perdagangan serta jasa yang banyak berhadapan dengan anggota dan konsumen koperasi. Hasil mentoring selanjutnya dilanjutkan dengan refleksi dari masing-masing karyawan untuk melihat sejauh mana perkembangan aspek individu pasca mengikuti program PKM selama dua tahun. Proses terakhir dari tahap kedua berupa Focus Group Discussion (FGD) dengan pimpinan koperasi dan kepala setiap divisi untuk memantau sejauh mana peningkatan kinerja masing-masing karyawan setelah mendapat pelatihan yang focus pada aspek individu. 


\section{Tahap Pelatihan aspek soft skill (Penguasaaan Bahasa Asing dan Teknologi)}

Pelatihan tahap 4 diselenggarkaan pada April 2018 dengan focus pada penguasaan skill bahasa asing (Inggris) dan teknologi (internet, computer, website). Pelatihan dilakukan selama satu bulan dan dibagi dalam 4 kali pertemuan. Pelatihan bahasa asing diberikan oleh native sementara pelatihan computer dan website diberikan oleh dosen Information Teknologi (I.T). Pelatihan ini dikemas dalam active learning dimana materi diberikan dan langsung dipraktekkan oleh karyawan dalam kegiatan sehari hari. Pelatihan bahasa asing (Inggris) dan computer diberikan kepada seluruh karyawan untuk menambah kompetensi soft skill namun, pelatihan website diberikan khusus pada divisi I.T yang ada di KPSP Setia Kawan Nongkojajar hal ini bertujuan untuk menjaga kerahasian dari data-data yang masukkan kedalam website koperasi.

\section{Tahap Entrepreneur Enabler}

Pelatihan tahap 4 dilakukan pada tahun 2017 focus pelatihan untuk membentuk karyawan menjadi entrepreneur enabler. Pelatihan ini merupakan rangkan terakhir dari pelatihan jangka panjang pada karyawan KPSP Setia Kawan. Pelatihan ini dilakukan selama satu minggu dengan tahap praktikum selama 10 bulan. Durasi praktikum tahap 4 membutuhkan waktu lebih lama untuk mewujudkan bisnis yang baru. Pelatihan ini membekali karyawan dengan teori entrepreneurship, identifikasi peluang dan menciptakan bisnis sebagai sumber pendapatan diluar penghasilan dari KPSP Setia Kawan. Pelatihan dibagi dalam beberapa tahapan yaitu: a). Identifikasi peluang ekonomi yang ada disekitar karyawan. b). Penyusunan business plan dari masing-masing karyawan. c). Eksekusi bisnis melalui pembuatan produk/jasa untuk diperdagangkan sehingga dapat memberikan pendapatan tambahan. Pelatihan tahap "a" dan"b" diberikan selama 1 minggu namun pelatihan eksekusi (tahap "c") dilakukan selama 10 bulan.

Pasca pelatihan teori tim PKM Universitas Ciputra malakukan mentoring setiap tiga bulan untuk melihat progress eksekusi dari bisnis yang dijalankan oleh karyawan KPSP Setia Kawan Nongkojajar. Tujuan pendampingan ini adalah untuk memberikan sharing bisnis sehingga tim PKM juga dapat membantu karyawan untuk memecahkan kendala yang dihadapi karyawaan saat eksekusi bisnis. Diakhir dari tahap keempat karyawan diminta untuk sharing pengalaman eksekusi bisnis agar sesama karyawan mendapatkan tambahan ilmu berdasarkan kondisi dan pengalaman dari karyawan yang lainnya dalam menjalankan bisnis.

Berdasarkan uraian tahapan program PKM Universitas Ciputra yang bekerjasama dengan KPSP Setia Kawan dapat dilihat pada Gambar 1

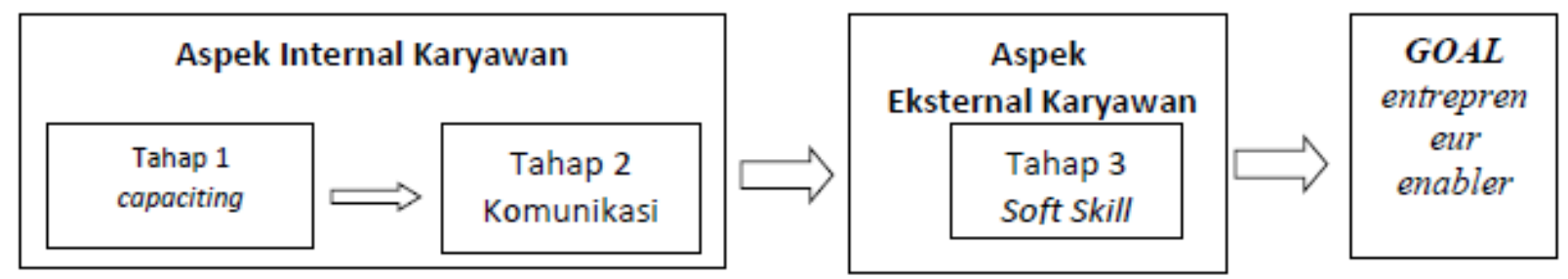

Gambar 1. Diagram Program Pengabdian Kepada Masyarakat

\section{HASIL DAN PEMBAHASAN}

Program Pengabdian Kepada Masyarakat (PKM) yang yang diberikan kepada karyawan koperasi KPSP Setia Kawan Nongkojajar selama 4 tahun berturut-turut memiliki outcomes karyawan menjadi entrepreneur enabler yang memiliki kompetensi di dunia kerja dan kemampuan mengembangkan bisnis diluar pekerjaan sebagai karyawan. 


\subsection{Tahapan 1 Pelatihan aspek internal penggalian potensi diri(Karakter, Potensi, Motivasi dan time management).}

Program pelatihan tahap 1 dibagi kedalam lima fase yang akan dilaluioleh peserta pelatihan. Hal ini dikarenakan untuk menciptakan entrepreneur enabler membutuhkan peningkatan kompetensi karyawan dari aspek internal(Up-Grade potensi diri), soft skill dan komunikasi dari karyawan. Tahapan up-grade potensi ini merupakan tahapan dasar dari program ini yang menjadi pondasi penting entrepreneur enabler. Berikut ini adalah gambaran program pengabdian masyarakat tahapan 1.

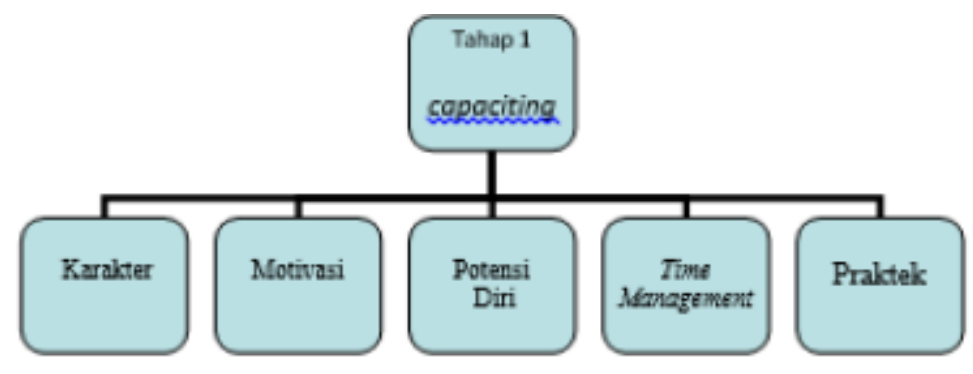

Gambar 2. Diagram Tahap 1 dari Program Pengabdian Kepada Masyarakat

Eksekusi tahapan 1 dari program PKM setiap karyawan diarahkan untuk memiliki karakter yang unggul (bertanggung jawab, jujur, disiplin, kerja keras dan peka terhadap lingkungan). Pelatihan karakter diberikan kepada karyawan melalui simulasi dan pembekalan karakter yang diisi oleh leader yang kompeten pada aspek karakte. Pelatihan karakter berlangsung selama 3 hari berturutturut. Lanjutan dari pelatihan karakter maka setiap karyawan diberikan motivasi untuk menjadi pribadi yang lebih baik melalui sesi motivasi semangat karyawan dibangkitkan kembali. Sesi motivasi diberikan kepada karyawan selama 1 hari yang di tutup denganmemutarkan kembali sejarah perjalanan koperasi KPSP Seria Kawan Nongkojajar.

Setelah karyawan memiliki pemahaman terkait karakter dan motivasi diri maka dilanjutkan dengan rangkaian kegiatan menemukan ide creative untuk melakukan pekerjaan agar lebih efisien. Ide creative ditemukan karyawan dengan cara menginventarisir potensi diri melalui pohon potensi diri. Setiap karwayan mengevaluasi potensi dasar yang dimiliki dan kemungkinan pengembangan potensi yang ada sehingga dapat menghasilkan kinerja yang optimal saat bekerja sebagai karyawan maupun, sebagai seorang entrepreneur dengan jalan mengembangkan potensi diri diluar jam kerja namun tetap dapat menghasilkan tambahan pendapatan bagi keluarga. Hal menarik dari penggalin potensi diri adalah ditemukannya potensi individu yang berbeda-beda. Karyawan wanita memiliki potensi membuat produk makanan, pengadaan jasa, dan kerajinan tangan. Karyawan yang pria memiliki potensi kemampuan dalam pengadaan jasa otomotive dan peternakan.

Potensi diri dalam bentuk ide creative yang sudah di temukan oleh karyawan selanjutnya di break down dalam time line kerja. Pada tahapan ini karyawan sudah mampu melihat bagaimana kondisi pengelolaan diri dia selama ini. Karyawan menemukan time management kurang efektif. Sebagian besar karyawan mengalokasikan waktu untuk kegiatan yang tidak productive seperti: menggunakan social media, istirahat, diskusi dengan tetangga di warung kopi dan menonton serial TV (sinetron, drama, acara televisi lainnya). Karyawan mulai diminta menyusun alokasi waktu selama 24 jam sehari. Berdasarkan kegiatan tersebut karyawan mulai mengalokasi waktu untuk kegiatan yang productive di lingkungan kantor maupun di luar jam kerja sebgai karyawan di koperasi KPSP Setia Kawan Nongkojajar. Karyawan mulai mengalokasikan waktu untuk meeksekusi kegiatan productive untuk menghasilkan pendapatan tabahan di luar gaji. Karyawan 
berhak membawa list alokasi waktu yang sudah disusun selama pelatihan untuk diterapkan selama 6 bulan berikutnya. Tim PKM melakukan mentoring kepada karyawan koperasi 6 bulan pasca pelatihan dan hasil yang diperoleh dari 300 karyawan sebanyak 30 orang karyawan sudah mulai menjalankan ide creative sehingga mendapatkan tambahan pendapatan.

\subsection{Tahap 2 Pelatihan aspek internal (Komunikasi)}

Rngkaian pelatihan tahap 2 dilanjurkan pada tahun 2016 dengan durasi pelatihan selama dua minggu. Pelatihan ini dibagi dalam dua klaster yaitu: kluster karyawan sudah memiliki bisnis dan karyawan yang belum memiliki bisnis. Hal ini dilakukan untuk menindak lanjuti hasil dari pelatihan pertama 60 orang karyawan yang sudah mulai memiliki usaha sampingan diberikan pelatihan terkait komunikasi yang spesifik terkait handling complain untuk menghadapi konsumen dan komunikasi dalam organisasi. Pada sesi ini karyawan banyak menceritakan masalah komunikasi yang dihadapi selama menjalankan bisnis tidak jarang, produk/jasa mereka tidak di bayar konsumen hingga timbul pertengkaran dengan konsumen. Peserta pelatihan diberikan pemahaman terkait komunikasi serta tips dan trik untuk berkomunikasi dengan konsumen. Sesi ini pemateri memberikan praktek cara berkomunikasi menggunakan komunikasi lisan maupun tulisan. Panduan praktis 3.S (Senyum, Sapa dan Salam) sehingga mudah di praktekkan ketika menjalankan usaha.

Pelatihan tahap dua dilakukan berkelompok dimana, karyawan yang belum memiliki bisnis mendapatkan pelatihan komunikasi terkait komunikasi pada sebuah organisasi (KPSP Setia Kawan Nongkojajar). Karyawan yang mendapat pelatihan pada kelompok ini diajarkan bagaimana cara komunikasi dengan pimpinan, rekan sejawat maupun dengan komunikasi dengan anggota dan konsumen di koperasi. Karyawan koperasi terkadang mendapat complain/amarah dari anggota koperasi yang produk susunya dikembalikan. Selama pelatihan ini karyawan diberikan simulasi dan membahas kasus-kasus terkait masalah komunikasi yang sering dihadapi pada lingkungan koperasi. Pelatihan ini menggunakna metode eksperimen selama pelatihan dibangun kondisi menyerupai kondisi yang sehari - hari dihadapi oleh karyawan sehingga mempermudah peserta untuk praktek dalam berkomunikasi. Pasca mengikuti pelatihan tim PKM melihat perubahan yang besar dalam hal cara karyawan berkomunikasi. Konflik komunikasi anatara sesame karyawan, anggota dan pelanggan koperasi mengalami penurunan. Hasil FGD dengan peserta karyawan menyimpulkan pelatihan tahap 3 memberikan mereka panduan praktis yang mudah diterapkan ketika berkomunikasi. Penerapan komunikasi yang benar berlangsung secara terus menerus yang pada akhirnya menjadi budaya postip yang baru dan berkembang di Koperasi KPSP Setia Kawan. Secara tidak langsung penerapan komunikasi menjadi koneksi yang menghubungkan setiap karyawan yang ada. Pokharel, M. P., \& Ok Choi, S. (2015) dalam penelitiannya berhasil membuktikan tingkat organisasi (terutama koneksi sistem) memiliki hubungan positif dan berhasil membangun hubungan antara karakteristik di tingkat individu / kelompok untuk pembelajaran dan peningkatan kinerja sebuah organisasi. Berikut ini adalah dokumentasi kegiatan pelatihan tahap kedua.
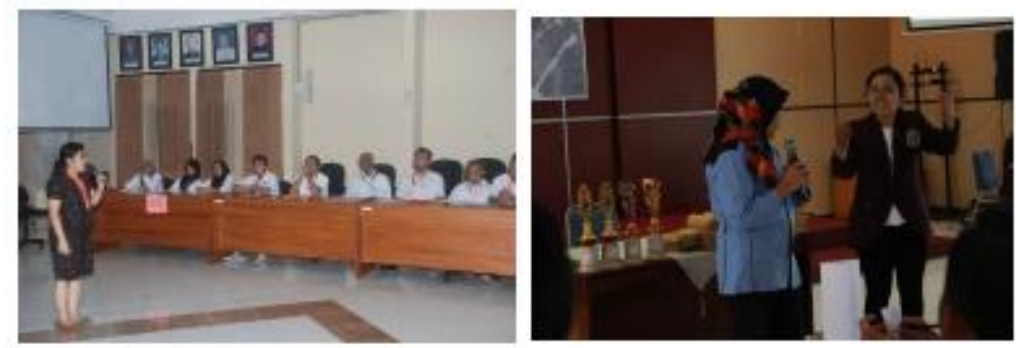

Gambar 3. Tahap 2 (Komunikasi) dari Program Pengabdian Kepada Masyarakat 


\subsection{Tahap 3 Pelatihan aspek eksternal (Penguasaaan Bahasa Asing dan Teknologi)}

Pelatihan tahap ketiga berlangsung selama satu bulan dimana karyawan dibekali dengan kemampuan bahasa asing (Inggris) dan penggunaan computer dan website. Karyawan mendapatkan pelatihan selama satu bulan dengan metode intensif. Setiap karyawan di bentuk dalam kelompok kecil sehingga mempermudah pengajar (native) untuk menstimulus kapasitas penguasaan bahasa asing. Tahap awal dilakukan pretest sehingga peserta pelatihan memiliki kelompok sesuai dengan kapasitas penguasaan bahasa asing. Native mengawali dengan memberikan materi dasar seputar writing, reading and listening. Masing-masing peserta mulai menggunakan bahasa Inggris yang sederhana dalam kegiatan sehari-hari khususnya di jam kerja.

Pada akhir sesi karyawan diberikan tugas untuk menceritakan kembali bagaimana kondisi pada saat mereka pelatihan dalam bahasa asing. Native juga melatih skill karyawan dengan memberikan film yang menggunakan bahasa Inggris lalu peserta diminta menceritakan kembali synopsis film menggunakan bahasa Inggris. Karyawan yang berada dalam divisi perdagangan sangat terbantu dengan adanya pelatihan ini hal ini dikarenakan mereka sering bertemu dengan konsumen asing yang ingin berlibur ke Bromo dan singgah di minimarket koperasi untuk berbelanja. Selama pelatihan tim PKM membuat treatment kondisi seperti kondisi kerja dari karyawan seperti baisanya. Kondisi simulasi berhubungan dengan bagaimana cara berkomunikasi dengan konsumen asing yang berbelanja (menjelaskan harga barang, fungsi dan mengucapkan terima kasih). Karyawan divisi perkantoran juga diberikan kesempatan melakukan simulasi bagaimana cara menghadapi tamu asing yang ingin melakukan studi banding ke koperasi hal ini terkait penjelasan mengenai kondisi koperasi (unit bisnis, kapasitas produksi, sejarah dan perkembangan koperasi) yang semuanya dilakukan dalam bahasa Inggris. Hasil dari pelatihan ini mampu upgrade skill kemampuan berbahasa Inggris karyawan sehingga mampu berinteraksi dengan orang asing menggunakan bahasa Inggris.

Pelatihan computer diberikan kepada seluruh karyawan focus pelatihan pada penggunaan teknologi (computer). Seluruh karyawan diberikan panduan praktis dan praktikum langsung penggunaan computer (Office dan Internet). Setiap karyawan membawa labtop dan mulai praktek menggunakan excel, Ms. Word untuk mempermudah pekerjaan di kantor. Sesi kemudian dilanjutkan dengan pengenalan internet dimana para karyawan dibekali dengan praktikum membuat email, google calendar, dan browsing untuk mempermudah mendapatkan informasi. Selama pelatihan computer ini berlangsung karyawan pada awalnya terlihat kesulitan untuk praktek namun pada minggu kedua karyawan sudah mulai mampu menggunakan computer. Pada minggu terakhir pelatihan tahap ini semua karyawan sudah mulai mengaktifkan google kalender sebagai media untuk mempermudah pekerjaan, menggunakan email sebagai sarana korespondensi. Google kalender membantu menyusun jadwal semua pengurus koperasi sehingga seluruh pengurus dapat menghadiri rapat dan agenda kerja koperasi. Penggunaan excel mempersingkat waktu pelaporan dan divisi susu dan semua laporan dikirimkan via email. Hal ini menjadi solusi untuk mendapatkan data real time sehingga manager koperasi dapat dengan cepat mengambil keputusan yang behubungan dengan kegiatan operasional.

\subsection{Tahap 4 Entrepreneur Enabler}

Rangkaian program pengabdian masyarakat (PKM) bertujuan untuk menciptakan entrepreneur enabler diantara karyawan koperasi yang sudah mengikuti pelatihan selama empat tahun. Pada tahapan berhasil menemukan tiga puluh karyawan yang sudah memiliki bisnis/usaha sampingan selain berprofesi sebagai karyawan koperasi. Karyawan yang yang sudah memiliki bisnis/usaha sampingan sebagai sumber pendapatan disebut entrepreneur enabler. Jenis usaha yang dijalankan oleh entrepreneur enabler diantaranya: usaha rajutan, bisnis kue kering, minuman tradisional, jasa 
pijat, jasa otomotive, bisnis snack, retail (warung). Pendapatan yang diperoleh dari bisnis entrepreneur enabler berkisar diantara Rp. 500.000 - Rp. 3.000 .000 setiap bulannya. Tahapan ini merupakan tahapan yang paling sulit karena dari 300 karyawan hanya $10 \%$ yang berhasil menciptakan usaha dan mengahsilkan pendapatan dengan umur bisnis lebih dari enam bulan. Karyawan yang mengikuti pelatihan tahap 4 totalnya berjumlah 300 orang namun $50 \%$ hanya mampu sampai taham mengusun business plan namun gagal pada tahap eksekusi bisnis. $40 \%$ karyawan lainnya mampu menciptakan bisnis namun tidak berhasil mempertahakan usaha operasional minimal 6 bulan hal ini dikarenakan: Keliru menetapkan HPP, analisis resiko yang kurang maksimal, kwalitas produk yang dihasilkan belum terstandarisasi, kesalahan dalam memilih media marketing, SOP, dan maslah terkait legalitas. Proses bisnis yang dijalankan entrepreneur enabler menjadi pengalaman sekaligus pedoman untuk mengembangkan bisnis meluputi aspek: aspek karakteristik, indentifikasi peluang kreativitas dan inovasi (Yeoh, K. K., 2017). Antusiasme peserta pelatihan untuk menjadi Entrepreneur Enabler terlihat pada dokumentasi ini.
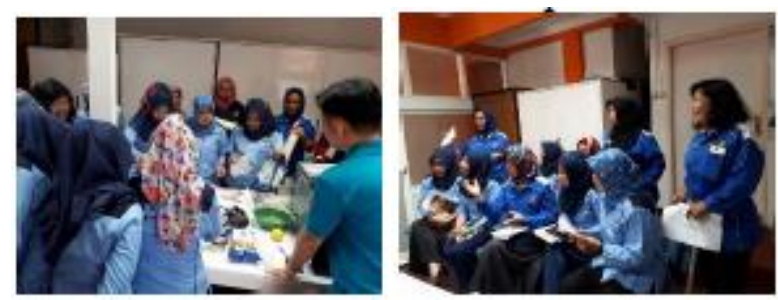

Gambar 4. Tahap 4 (Entrepreneur Enabler) dari Program Pengabdian Kepada Masyarakat

Tiga puluh entrepreneur enabler mampu bertahan karena memiliki katakter yang unngul (kerja keras, jujur, tekun dan disiplin) dan memaksimalkan potensi, skill, kemampuan komunikasi, soft skill (bahasa Inggris, computer dan internet). Entrepreneur enabler yang berasal dari karyawan koperasi dengan tingkat pendidikan Sekolah Dasar (SD) mampu mengoprasikan computer sehingga mulai mempelajari cara membuat produk, memasarkan barnag/jasa dan meyusun laporan keuangan dengan excel. Proses ini membuat tim PKM melakukan mentoring dengan Entrepreneur enabler sehingga dapat memberikan solusi terkait masalah-masalah yang dihadapi dalam membangun bisnis. Pada tahan ini entrepreneur enabler yang menjalankan bisnis snack dan kue kering sudah mulai mengurus legalitas (PIRT) dan melakukan uji di laboratorium makanan. Ekesuki bisnis sesuai dengan temuan Bina, O., \& Ricci, A. (2016) yang menjelaskan bahwa penggabungan proses iteraktif, partisipatif dengan dimensi eksploratif, normatif dan memvisualisasikan, masa depan URBACHINA memberikan kemungkinan mengembangkan model yang sudah ada. Menetapkan ruang lingkup proses untuk memasukkan alternatif yang normatif, diinginkan dan instrumental perkotaan.

Tim PKM melakukan mentoring dan evaluasi terkait perkembangan bisnis melalui diskusi dengan entrepreneur enabler, mentoring via online maupun tatap muka sehingga komunikasi antara tim PKM tetap terjalin. Tim PKM active membagikan peluang dan ide bisnis kepada Entrepreneur enabler agar memotivasi untuk meningkatkan kapasitas usaha. Tiga puluh entrepreneur enabler active melakukan sharing kepada sesama karyawan terkait perkembangan bisnis yang dijalankan sehingga mampu memotivasi karyawan yang belum memiliki bisnis. Sharing bisnis bertujuan untuk memperluas jaringan bisnis. Soetanto, D. (2017) menemukan entrepreneur mampu mengembangkan jaringan, sebagian besar memiliki ikatan kuat untuk pembelajaran eksploitatif. Gambar ini merupakan hasil karya peserta. 


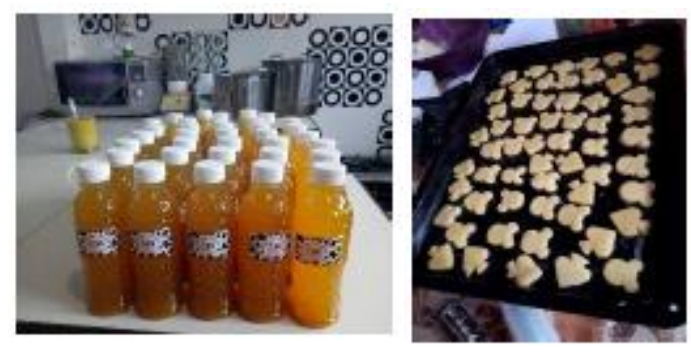

Gambar 5. Produk Karya Entrepreneur Enabler

\section{KESIMPULAN DAN SARAN}

Program entrepreneur enabler yang diberikan kepada karyawan KPSP Setia Kawan Nongkojajar melalui metode PALS (Participatory Action Learning System) mampu menciptakan 30 entrepreneur enabler. Tim PKM memberikan simulasi selama pelatihan sesuai dengan fakta yang dihadapi oleh karyawan. Program ini terdiri dari tahapan 1-4 metode PALS berpusat pada peserta pelatihan sehingga dapat memaksimalkan seluruh potensi karwayan. Program dilengkapi pemahaman konsep teori, simulasi (treatment), praktek dan mentoring, FGD dan evaluasi yang berhasil mengatasi masalah yang timbul di koperasi. Rangkaian pelatihan mampu meningkatkan kwalitas kinerja karyawan pada beberapa aspek: a).data laporan divisi keswan dan susu segar sudah reall time. b). Data inventori gudang sudah menggunakan system sehingga persentase selisih barang yang hilang mengalami penurunan, c). Penggunaan google calendar menjadi media pengaturan agenda kerja semua anggota, pengurus dan karyawan koperasi, d). Karyawan mulai terbiasa berlatih mengggunakan bahasa Inggris, e). Setiap karyawan memiliki kemampuan time management sehingga semua pekerjaan dapat diselesaikan sesuai deadline. f).Motivasi, karakter dan komunikasi setiap karyawan semakin meningkat, g). terdapat 30 entrepreneur enabler yang sudah memiliki tambahan pendapatan tambahan diluar gaji sebagai karyawan di koperasi KPSP Setia Kawan Nongkojajar.

\section{UCAPAN TERIMA KASIH}

Penelitian ini terselenggara berkat bantuan dari Universitas Ciputra Surabaya dan Koperasi KPSP Setia Kawan Nongkojajar yang bersedia memberikan bantuan untuk terselenggaranya penelitian ini.

\section{REFERENSI}

Bina, O., \& Ricci, A. (2016). Exploring participatory scenario and storyline building for sustainable urban futures-the case of China in 2050. foresight, 18(5), 509-534.

Brink, T., \& Madsen, S. O. (2015). Entrepreneurial learning requires action on the meaning generated. International Journal of Entrepreneurial Behavior \& Research, 21(5), 650-672.

Hietanen, L., \& Järvi, T. (2015). Contextualizing entrepreneurial learning in basic and vocational education. Journal of Enterprising Communities: People and Places in the Global Economy, 9(1), 45-60.

Kassean, H., Vanevenhoven, J., Liguori, E., \& Winkel, D. E. (2015). Entrepreneurship education: a need for reflection, real-world experience and action. International Journal of Entrepreneurial Behavior \& Research, 21(5), 690-708.

Pokharel, M. P., \& Ok Choi, S. (2015). Exploring the relationships between the learning organization and organizational performance. Management Research Review, 38(2), 126-148. 
Rae, D. (2017). Entrepreneurial learning: peripherality and connectedness. International Journal of Entrepreneurial Behavior \& Research, 23(3), 486-503.

Soetanto, D. (2017). Networks and entrepreneurial learning: coping with difficulties. International Journal of Entrepreneurial Behavior \& Research, 23(3), 547-565.

Thompson, J., \& Downing, R. (2007). The entrepreneur enabler: identifying and supporting those with potential. Journal of Small Business and Enterprise Development, 14(3), 528-544.

Vesper, K. H., \& Gartner, W. B. (1997). Measuring progress in entrepreneurship education. Journal of Business venturing, 12(5), 403-421.

Yeoh, K. K. (2017). Entrepreneurship students distilled their learning experience through reflective learning log. Journal of Research in Innovative Teaching \& Learning, 10(2), 126-142. 